\title{
The neglected roots of Switzerland's national economy: The key role of peasantry
}

\author{
G.Vallet
}

Guillaume VALLET, Associate Professor in economics and sociology, Department of Economics, University of Grenoble Alpes, Grenoble, BP 47, 38040.

E-mail: guillaume.vallet@univ-grenoble-alpes.fr

The article aims to identify the role of peasantry in the Swiss national production system and in the Swiss society in general. There is an evident paradox when considering the peasantry in Switzerland: though its economic power has been decreasing over time, its political power remains. The author uses the archival data to resolve this paradox and prove the key role of the Swiss peasantry in Switzerland from the historical and institutional perspectives in creating the "Swiss model" based on money. Therefore, the Swiss peasantry has always been involved in the national decision-making and represents the cultural basis of the local scale (centripetal forces) in this small open economy (centrifugal forces). The article focuses on the Swiss case to reveal the relationship between the peasantry as a social group with specific functions and the national production system. The latter refers to the system of different sectors of the national economy, which requires a "glue" in the form of monetary policies that are consistent with economic and social structures. According to Schumpeter, "nothing demonstrates so clearly what a people is made of than how it conducts its monetary policy... everything that a people desires, does, suffers, is reflected in a people's monetary system" (Schumpeter, 2014: xiv). The article aims to explain the extent to which peasants as a social group matter in the Swiss national production system. The author believes that this group has also participated in developing a strong economic system in Switzerland relying on the Swiss franc, therefore the term "peasantry" implies both economic and cultural features in the historical context. The first part of the article identifies current characteristics of Swiss peasants as a social group; the second part describes their role in the 1930 s, i.e. in the development of the strong national production system; and the third part sums up the first two by explaining the key role of peasantry in Switzerland in a broad sense.

Key words: Switzerland; peasantry; national history; national production system; economic and social model; social and economic institutions

DOI: $10.22394 / 2500-1809-2017-2-4-56-69$

Although the role of agriculture in the economic growth of the developed countries is low according to the today's standards, agriculture still benefits from a high social status for it refers to culture in both productive and social senses. The population of developed countries can be considered a historical "legacy" of the people for whom the cultivation of land was the basis of individual and collective identities. Thus, many scholars emphasize the economic and social consequences 
of the transition from peasantry to agriculture in the developed countries (Mendras, 1967): becoming a big farmer means primarily a market orientation and seeking profit instead of being socially involved in the life of a small community and informal economy.

However, agriculture is still a major concern for the developed countries. Its survival depends on its ability to offer attractive prices and quality products. Although the added value in agriculture is low per se, it entails a significant growth of productivity as well as spillover effects for the national economy. That is why its competitiveness depends on the exchange rates: to support exports of food and raw materials the central bank should manage the exchange rates according to the country's productive specialization, which determines the importance of agriculture for the national economy.

\section{Swiss peasants: an overview}

As in other developed countries, the role of the peasantry in Switzerland has sharply declined over time, especially over the last fifty years. Table 1 presents this declining trend in comparison to industry and service sectors in Switzerland for the period of 1960-2000.

Moreover, as Table 2 shows, in agriculture there are fewer enterprises than in other sectors.

According to the international data, Switzerland belongs to the group of countries with the lowest share of farmers considering the total number of workers (Graph 1).

Several factors determine this trend, such as the increasing role of the service sector in the national economy, the growth of productivity, and the internationalization of trade. In general, today the contribution of the primary sector to GDP is extremely low (Graph 2).

Moreover, some products have suffered more than others. As Graph 3 shows, "pure" agricultural production declines though the Swiss agriculture still relies on "safe-haven" production (mainly milk, cheese, and beef products). The national economy compensates for this decline by services related to agriculture (Graph 3).

Though the agricultural sector does not seem important for Switzerland due to the apparently low impact on GDP and employment, it has some economic "spillover effects" for the country. It should be mentioned that agriculture has many relationships with other sectors, especially with the service sector as the previous graph indicates; there are also many ties between agriculture and industry considering machinery, chemistry, and so on (see Ponsot \& Vallet, 2013). Switzerland differs from other countries by the high subsidies it allocates to peasantry despite its lower productivity than in other countries, certainly, because the Swiss peasantry benefits from protectionism. Moreover, the Swiss Federal Council has always supported the peasantry either by subsidies or by incentives to export. Thus, the annual subsidies allo-
G. Vallet

The neglected roots of Switzerland's national economy: The key role of peasantry 


\begin{tabular}{|c|c|c|c|c|c|c|}
\hline \multirow[t]{5}{*}{ ИстоРИя } & Sectors & 1960 & 1970 & 1980 & 1990 & 2000 \\
\hline & Agriculture & 14.5 & 8.5 & 6.9 & 4.2 & 4.5 \\
\hline & Industry & 46.5 & 46.2 & 38.1 & 32.2 & 26.4 \\
\hline & Services & 40 & $45 \cdot 3$ & 55.0 & 63.6 & 69.1 \\
\hline & Total & 100 & 100 & 100 & 100 & 100 \\
\hline
\end{tabular}

Source: Author's calculations based on the data of Office Fédéral de la Statistique (2017).

Table 2. Distribution of enterprises and jobs in Switzerland in 2015

\begin{tabular}{lllll}
\hline Enterprises & Agriculture & Industry & Services & Total \\
\hline 0-9 & 54,963 & 74,236 & 390,498 & 519,697 \\
$10-49$ & 318 & 12,671 & 22,224 & 35,213 \\
$50-249$ & 21 & 2,631 & 4,351 & 7,003 \\
More than 249 & 0 & 448 & 817 & 1,265 \\
Total & 55,302 & 89,986 & 417,890 & 563,178 \\
Total number of jobs & 159,923 & $1,098,391$ & $3,045,006$ & $4,303,320$ \\
\hline
\end{tabular}

Source: Author's calculations based on the data of Office Fédéral de la Statistique (2015)

cated to peasantry by the Swiss government is 2.8 billion Swiss francs, which is a specific measure for the relatively non-interventionist country (Schoenenberger \& Zarin-Nejadan, 2001). Among other reasons, this explains why Switzerland was so reluctant to join the World Trade Organization or the European Union despite being an open economy depending on external markets, especially European markets (Vallet, 2012).

However, this public support for agriculture has been an integral geographical feature of the country: only $20 \%$ of the land in Switzerland is suitable for production. Nevertheless, in the nineteenth century Swiss farmers succeeded in turning these constraints into advantages with the cooperatives model. The latter allowed them to become stronger in the internal market, and then to increase exports. In other words, the Swiss economic model relies on cooperation (Church \& Head, 2013), such as strong alimentary cooperatives (Migros, for instance). That is why the Swiss peasants became an important social group capable of influencing national policies in their favor despite their economic weakness. To understand such a paradox, we should consider the historical roots of both the strength of the Swiss peasantry and the national production system. 


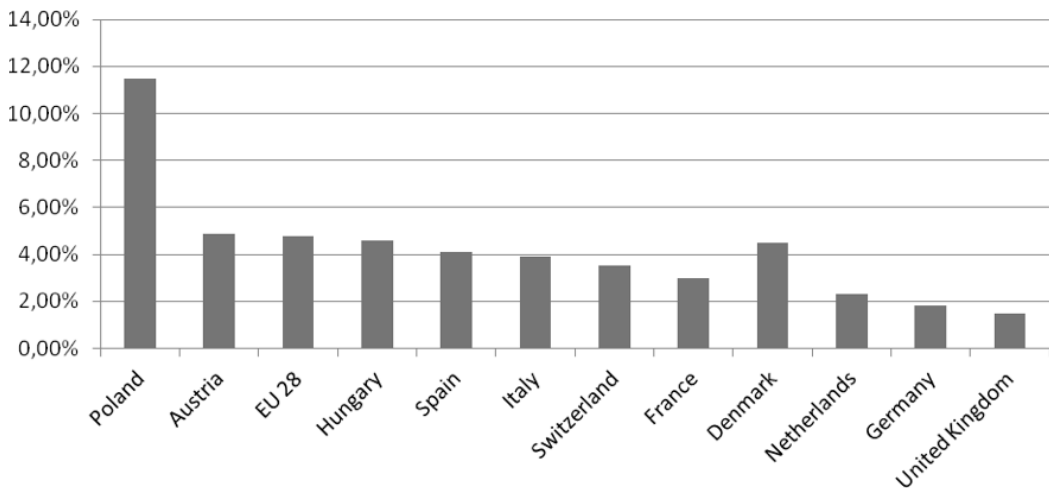

\section{G.Vallet}

The neglected roots of Switzerland's national economy: The key role of peasantry

Source: Author's calculations based on the data of the European Commission, 2016

Graph 2. Contribution of the agricultural added value to the national added value in 2014

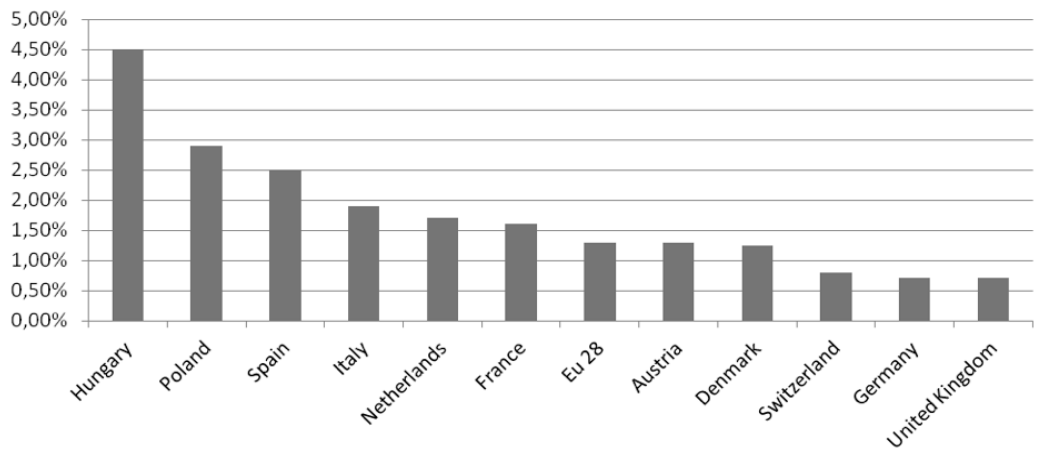

Source: Author's calculations based on the data of the European Commission, 2016

Graph 3. Value of production in agriculture

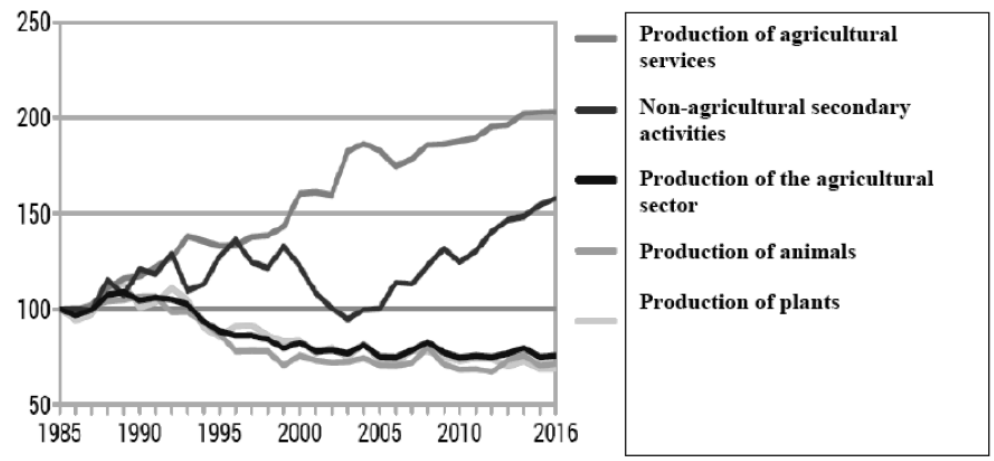

Source: Author's calculations based on the data of the European Commission, 2016 


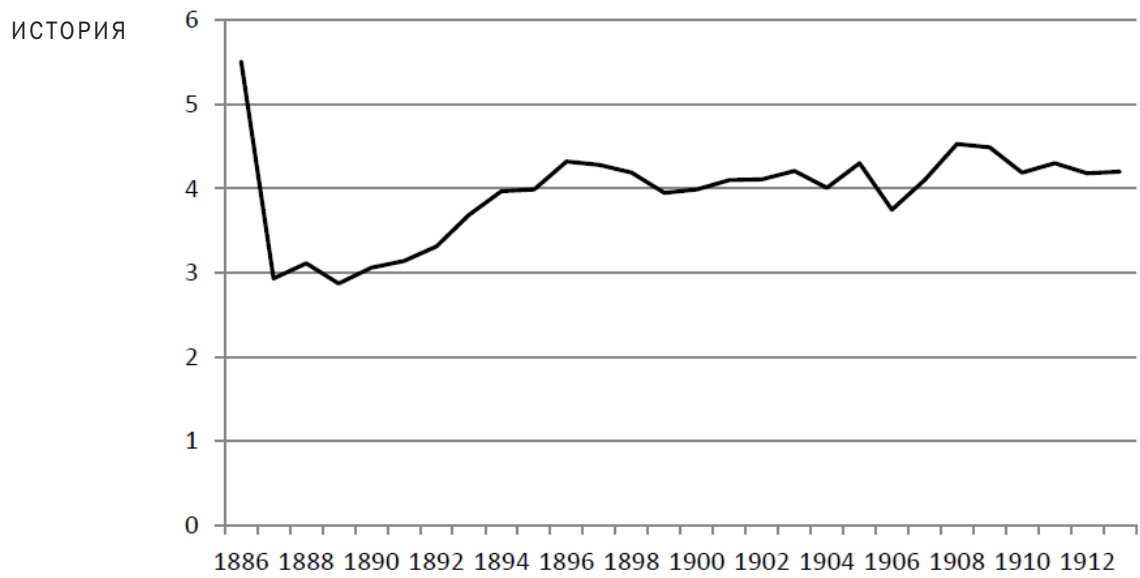

Source: Statistique du Commerce de la Suisse avec l'Étranger

\section{The "peasant era" in the history of Switzerland (1920s-1930s)}

Although this part of the article mentions the end of the nineteenth century, when the key institutions of the Swiss peasantry were established, it focuses on the 1920s-1930s, i.e. the "peasant era" in the Swiss history, when this social group was undoubtedly at the summit of its power. Such strength was to a large extent the result of the fight of the Swiss Union of Peasants (SUP) that ensured the key role of the Swiss peasants to be recognized in the country, for instance, in the 1920s the SUP determined the custom policies (Humair, 1992). During this decade, the SUP was among the most important actors of the Swiss foreign policy (Dérobert, 1926).

Nevertheless, it is noteworthy that there was no peasant power in the previous decades and especially in the previous century, in which living in Switzerland was considered a kind of a "malediction" for several reasons. First, some significant European crises in the 1880 s negatively affected the Swiss agriculture. Swiss peasants were weak and disunited: for instance, the Peasant Union created in 1893 broke up quickly. Second, the Swiss external policy was guided by the interests of industry and by the powerful "Vorort" as its representative institution. Even under the protectionism of the second half of the nineteenth century, which ensured the development of industry, the "Vorort" supported free trade in the interests of industry. In general, there was a "moderate and selective" protectionism in Switzerland (Humair, 2004). It should be noted that at the end of the nineteenth century the Swiss protectionism was called "protectionism of combat" (Humair, 2004) for it allowed the fixed costs of exports to be minimized to secure outlets. Graph 4 shows the development of the average trade tariffs. 
Such a tax policy helped the Swiss economy to take off under the starting globalization, and Switzerland became the second in the world after Argentina in terms of the economic growth rate, which explains the emergence of the concept "Swiss miracle" in the nineteenth century. However, it is important to emphasize that though the average taxes were lower in Switzerland than in the rest of Europe, there were significant differences between products. For instance, foreign industrial goods were taxed higher to protect the Swiss "infant" industry, while agricultural products were not - taxes were low and were declining from the late 1880 s to the early 1900 s compared to other products (Table 3). This trend persisted in the 19oos and 1910s (Table 4).

Tables 2 and 3 reveal that the peasantry was not a unified group capable of defending its collective interests. Thus, the sectors of dairy and cattle production were interested in exports, while others such as wine production demanded protection. There was also a split between sectors connected to the agro-alimentary industry (dairy products) and others that were more isolated or internal-market-oriented (fruits, vegetables, wine). The Federal Council sometimes benefited from this split when implementing its policies for it believed that the peasantry as a social group did not play an important role in Switzerland at that time (Laur, 1919), which is why it focused in the development of industry.

The creation of the Swiss Union of Peasants in 1897 changed the situation. The SUP was a unified and well-organized political organization. For instance, it established the journal Le Paysan Suisse, which helped to disseminate information about the Swiss peasantry throughout the whole country. The SUP was able to bargain with the government, that is how in 1903 it got the right to assist the government in every commercial treaty. The SUP became powerful in ensuring protectionism and offsetting the free-trade intentions of industry, which was useful under the new legislative conditions for protectionism in 1903. The charismatic leader of the SUP from 1898 to 1939, Ernst Laur, played the key role in this fight and managed to convince the Federal Council to maintain and even raise tariffs to ensure permanent income for the Confederation. The SUP's role was reinforced under the World War I, when the SUP and the Swiss peasantry in general benefited from the positive public opinion. According to the Swiss population, the peasantry succeeded in feeding the country ${ }^{1}$ and ensuring revenues from exports of the Swiss agricultural products to the belligerents. Moreover, the latter did not break the principle of neutrality as one of the key political ideas of Switzerland (Vallet, 2010).

1. For instance, the Union Centrale des Producteurs Suisses de Lait was to provide the Swiss cities with milk and cheese.
G. Vallet

The neglected roots of Switzerland's national economy: The key role of peasantry 


\begin{tabular}{llll}
\hline история & 1888 & 1892 & 1905 \\
\cline { 2 - 4 } Waste and fertilizers & 0.23 & 0.73 & 0.52 \\
Chemicals & 2.39 & 3.38 & 4.45 \\
Glass & 20.57 & 23.74 & 23.08 \\
Wood & 3 & 5.12 & 5.77 \\
Agricultural products & 1.79 & 0.71 & 0.76 \\
Leather & 2.10 & 2.80 & 3.48 \\
Books & 0.54 & 1.31 & 1.55 \\
Machinery & 30.67 & 3.69 & 3.82 \\
Metal & 3.00 & 2.20 & 2.57 \\
Minerals & 2.02 & 2.47 & 2.19 \\
Food products & 4.37 & 5.80 & 7,67 \\
Oil and fats & 1,70 & 2,73 & 2,77 \\
Paper & 6.95 & 9.32 & 12.21 \\
Textiles & 0.93 & 1.55 & 2.60 \\
Animals & 0.93 & 2.42 & 2.29 \\
Pottery & 9.84 & 11.47 & 13.48 \\
Other & 2.26 & 5.53 & 7.93 \\
\hline
\end{tabular}

Source: Statistique du commerce de la Suisse avec l'Étranger

The Swiss industrial bourgeois realized that it was no longer possible to ignore the peasantry, especially as a source for preventing workers from being too revolutionary. Therefore, the industry turned to the peasantry stressing its positive role for Switzerland from both economic and cultural perspectives. For instance, Laur's perception of external tariffs was helpful for the bourgeois in defending the lower taxation of capital: the bourgeois increasingly interested in free trade in the first decades of the twentieth century accepted the growth of some external tariffs provided the decrease of capital inflows. The socalled "peasants-bourgeois bloc" was created.

However, this did not deprive the Swiss peasantry from a certain degree of independence as being an ally of workers on some issues, for instance, on fighting bank secrecy in the 1920s to increase national revenues instead of decreasing trade tariffs. Furthermore, Laur suggested import and export taxes for Swiss industry (ranging from 


\begin{tabular}{llll}
\hline Products & 1906 & 1910 & 1913 \\
\hline Food products & 6.41 & 7.46 & 6.86 \\
Animals & 4.13 & 3.47 & 2.70 \\
Leather & 3.55 & 3.61 & 3.58 \\
Seeds, plants & 0.41 & 0.30 & 0.28 \\
Wood & 5.92 & 6.11 & 6.15 \\
Paper & 5.95 & 7.15 & 7.11 \\
Textiles & 2.31 & 1.89 & 2.67 \\
Minerals & 0.83 & 0.55 & 0.49 \\
Clay, sandstone, pottery & 13.86 & 13.40 & 12.72 \\
Glass & 19.23 & 19.09 & 17.05 \\
Ores and metals & 2.07 & 2.66 & 2.57 \\
Machinery and vehicles & 5.84 & 5.79 & 5.43 \\
Clocks, watches & 3.49 & 3.47 & 3.20 \\
Chemicals & 4.13 & 4.33 & 3.89 \\
Other & 6.33 & 6.35 & 6.54 \\
\hline
\end{tabular}

G. Vallet

The neglected roots of Switzerland's national economy: The key role of peasantry

Source: Statistique du commerce de la Suisse avec l'Étranger

o to $2 \%)$ to increase the prices of foreign imports. Considering the issue of inflation, Swiss peasants were generally supporting workers rather than the bourgeois for they believed that the growth of prices guaranteed then regular profits. Finally, in 1921 a tariff on trade in peasantry's interests was introduced, which can be considered the backbone of peasants" power in this and the following decades. Thus, Switzerland was one of the less protectionist European countries before the WWI, but it became the most protectionist European country a decade later.

The Swiss peasantry devised a strategy that played a significant role in developing the national economy. In the 1920s, characterized by international turmoils, especially in the monetary and financial domains, Switzerland succeeded in winning a sustainable specialization in banking and financial sectors (Laurent \& Vallet, 2014). The sectors previously associated with industry have been increasingly determining the Swiss production system since that time. The Swiss industry could no longer rely on weak wages and low costs of production to become competitive: on the one hand, it required a high amount of 
64 capital, in particular inflows from abroad; on the other hand, it sought social peace to avoid costly strikes. Therefore, the Swiss banking and история financial sector supported this new system to attract international capital for its own sake and for the industry.

However, the inconvenient truth is that the government developed economic policies that were not always in the interests of peasantry. In the 1930s, when it became clear that the government aimed to ensure efficient productive specialization by supporting the industry, finance and banking sectors, the monetary orthodoxy became inevitable as a necessary condition to attract foreign capital (Laurent \& Vallet, 2014; Vallet, 2017). Although the orthodox monetary policies under the Great Depression was a too high price in the short run (Bordo \& James, 2007), it was decisive in developing a stable national production system in the long run. Thus, in 1929 the Swiss National Bank introduced the Gold Standard in the law as a strict rule for monetary policy (SNB). Similarly, the bank secrecy was officially introduced in 1934 to reinforce Switzerland's attractiveness for foreign capital (Laurent \& Vallet, 2014). However, the Gold Standard as a necessary condition for deflation was not in the interests of the Swiss peasantry that needed higher prices. Once again Laur opposed the policy that he called "the island of safe money" and took the side of "the island of prices" (Humair, 1992). He claimed that the negative impact of deflation on the agricultural production would not be alleviated by the decrease of labor costs: "Abroad, the capitalists lost their fortune and the peasants were able to repay their debts by means of depreciated money. Today, farmers pay back interest and debt service using paper, while in Switzerland their colleagues do so in gold-value. We cannot conclude that Switzerland should sacrifice its currency, but rather that Swiss debtors must obtain prices that are in harmony with the nature and level of their burdens" (Laur, 1932).

However, the position of Laur and of the peasantry in general was not clear. Laur, who in the 1930s worked in the Committee of the Bank of the SNB, supported the Gold Standard, as the economic and political leader of that time Schulthess confirms: "For agriculture also no gain would result from devaluation. Indeed, the optimist Laur in particular acknowledged that it would be difficult to maintain support to the peasantry after the devaluation" (Schulthess, 1943). This quote reveals that the Swiss peasantry succeeded in the 1930s. Thus, this social group agreed to support the choices of the economic, monetary and political authorities that served the creation of the national productiion system. However, this support was determined by the belief that the resulting revenues would help peasants to gain their own economic and political advantages. In other words, the long-term global economic advantages of the greater attractiveness of the country were to be shared with the peasantry through subsidies and legislative protection. Moreover, the Swiss peasantry had its first polit- 
ical representative in the Federal Council in 1929 - Rudolf Minger, which helped to bargain for advantages.

The above mentioned explanations show the extent to which the economic and political authorities had to take into account the demands of peasantry in the 1920s and 1930s because this social group possessed a significant political power. It should also be remembered that the Swiss peasantry was an important labor force because the number of workers in agriculture increased between the two world wars: in 1930, there were 12,000 local associations of the SUP with 670,000 peasants. According to Laur, "a Swiss economy as more agricultural and poor" is better than "a Swiss economy as more industrial and rich" (Landmann, 1928: 57), which was accepted by the political and economic authorities of the country. Edmund Schulthess officially confirmed this position at the International Conference of Agricultural Associations in September 1925 (Landmann, 1928).

Thus, the Swiss peasantry played the key role in developing a strong and diversified economy, and more widely a sustainable democracy, especially with respect to the ability to become smallholders (Landmann, 1928). The economic period of the 1920s and 1930s, the "Peasant Era" in Switzerland, created conditions for the strength of this social group that is still evident today albeit in a different form.

\section{Why the peasantry still matters in Switzerland}

The focus on the peasantry, particularly in historical perspective, is relevant for understanding the development of Swiss capitalism and democracy. Although the Confederation was officially established in 1848 , it became a real nation state only when the Swiss National Bank was created (1907) (Vallet, 2017). From the economic perspective, the Swiss franc enabled the Swiss economy to become a unified internal market, and money was a significant factor in building a strong productive economy. However, these conditions were determined by the Swiss authorities and people success in establishing relationships between all actors of production: banks and financial institutions, industry, workers, and peasants. Even though the peasants were becoming less and less important from the economic perspective (in terms of contributing to GDP), they remained an important social group for the country in which money "matters'. On the one hand, the Swiss peasantry has increasingly participated in industry, particularly in the agro-alimentary industry (Quartier, 1978). On the other hand, peasants constituted the Swiss national basis, especially through their role in the monetary system: money have positive effects provided their connection with productive economic structures forming a system consistent with the nature of monetary policies.

Money played the key role in the Swiss economic and political project that relied on the conflicts between social actors and thus ob-

G.Vallet

The neglected roots of Switzerland's national economy: The key role of peasantry 
tained the status of a "social anchor'. The political leader Musy in the 1930s summed this up well: "One said with a reason that our Swiss история franc is the main column on which our national political building is based. We have to preserve it... With such an economic structure as ours one can consider money as the one big financial enterprise in which all Swiss people, whatever economic groups they belong to, are interested" (Musy, 1933: 571). Therefore, money possess the status of an institution due to the framework that "coerces" (Vallet, 2017); however, it is an organic institution, because it evolves through the actions of its users (Dodd, 2014).

In Switzerland, money became the core of both economy and society to enhance prosperity, and peasants played their role by benefiting from it for two reasons. First, by playing the key role in developing the national production system the peasants increased acceptability and legitimacy of money: the users of money accept it because they believe in it and in the monetary institutions (Vallet, 2016). The peasants confidence in the SNB and the Federal Council was decisive for the Swiss franc: for instance, peasants were strong opponents of the policy of the Gold Standard in the 1930s, which allowed the Swiss franc not to be perceived as a weak institution for the country. Second, by defending their needs and political will by both consent and conflict, peasants played the crucial role in improving the Swiss democracy for they participated in national compromises. One should remember the regulative nature of conflicts within democracy (Touraine, 1994).

The mentioned developments emphasize the paramount point of the Swiss economic system: although it relies on liberal economy regarding the weak state interventionism, it supports the idea of regulation in which every economic group including peasantry plays a significant role. Federal or national institutions such as the Federal Council or the SNB (in charge of implementing the Swiss policies) consult with representatives of economic sectors before making decisions. For instance, Laur was a member of the SNB committee, which is still typical for representatives of the Swiss industry.

Thus, Switzerland succeeded in transforming its economic structures through different industrial revolutions moving from a "Manchester capitalism" to the "regulated capitalism" (Humair et al., 2012). However, the regulated capitalism in Switzerland does not mean state interventionism; rather, it refers to the system in which the state protects the economic trade only by law, and different organizations have the right to advise and influence the government in their own interests. From this perspective, the structure of the Swiss economy proves the diversity of types of capitalism despite its main features: pursuit for profit, rationalization (Boyer, 2015), and money to finance entrepreneurial projects. These features can take several forms according to cultural, sociological and historical conditions. The Swiss case indicates the extent to which economic issues must be embed- 
ded in social concerns to understand "the tricks of the trade" and social life in general.

Therefore, more broadly, the Swiss peasants have improved - and are still improving - the democratic functioning of the economy and society by maintaining local culture. The Swiss social and political basis consists of direct democracy, neutrality, and federalism that allows the Swiss peasantry to play a decisive role with its cultural patterns. The peasant culture supports local economic and social networks that reinforce federalism and democracy. It should be noted that local associations of the SUP are established within the cantons (there are still around sixty local associations in the country). Although the SUP is a federation, it supports independent peasantry and, contrary to some countries such as France, primarily small peasants: the average size of an agricultural enterprise is about 14 hectares, less than in the European Union (16 ha). This creates an equilibrated agricultural structure within the country, in which culture, norms and values prevent conflicts due to centrifugal forces.

In other words, even though the country relies on hyper-globalization regarding its productive structures, it also benefits from centripetal forces such as local cultures maintaining the internal specificities of the country, and the peasants play here a significant role. The political system enables Swiss peasants to have power through its legislation which resembles the American system. In Switzerland, there are two legislative bodies: the so-called "Conseil national" that represents Swiss citizens (1 deputy per 20,000 people), and the "Conseil des Etats" (2 deputies per canton and 1 per demi-canton) (Bouquet, 1995). The Conseil des Etats allows cantons with small populations, mainly rural, to defend their interests. They can benefit from about 10$15 \%$ of seats, which is far more than their economic weight. This disproportionate political power is an advantage for the whole country.

Switzerland is both a small, open and internally diversified country. Its internal functioning relies on decisions made by cantons and cities, and such a decision-making process corresponds to other two Swiss basic principles - direct democracy and federalism (Vallet, 2010). By participating in both national prosperity and national identity, the Swiss peasantry helps to prevent external shocks and to reinforce social links between different parts of the country. Certainly, the main challenge for the Swiss peasantry is to maintain its cultural and economic significance while facing serious environmental issues such as climate changes and organic production. The Swiss law (Article 104 of the Constitution) mentions three main objectives of the peasantry: providing food for the Swiss population, conservation of natural resources and landscapes, and the decentralized settlement.
67

G.Vallet

The neglected roots of Switzerland's national economy: The key role of peasantry 
In Switzerland, peasantry has often been neglected as a social group. Although there are some works on historiography or sociology

история of peasantry, none have highlighted their role and status in the Swiss economy and society. Based on the historical data, I have proved that the Swiss peasantry form the core of the "Swiss model" relying on the Swiss franc as the backbone of the national economy. This group has always been politically involved - directly or indirectly — in decision-making, though its economic impact decreased over time. From the cultural perspective, the Swiss peasantry reinforced local communities (centripetal forces) in a small open national economy (centrifugal forces). Thus, the Swiss case is insightful for the economic analysis within sociological and historical perspectives. The latter help to understand what being a Swiss peasant means from both individual and national points of view. Such an approach is useful for the study of the Swiss society development under the hyper-globalization process through the lens of the "Swiss peasant".

\section{References}

Bordo M., James H. (2007) De 1907 à 1946: enfance heureuse ou adolescence difficile? Banque Nationale Suisse 1907-2007. Zürich.

Bouquet J.J. (1995) Histoire de la Suisse. Paris.

Boyer R. (2015) Economie Politique des Capitalismes. Paris.

Church C., Head R.C. (2013) A Concise History of Switzerland. Cambridge.

Dérobert E. (1926) La Politique Douanière de la Confédération Suisse. PhD dissertation. Geneva.

Dodd N. (2014) The Social Life of Money. Princeton.

Humair C. (1992) L'influence de l'Union Suisse des Paysans sur la politique douanière de la Confédération Suisse durant les années 1920. Société Suisse d'Histoire Économique et Sociale, no 10, pp. 219-241.

Humair C. (2004) Développement Économique et État Central (1815-1914): Un Siècle de Politique Douanière Suisse au Service des Élites. Bern.

Humair C., Guex S., Mach A., Eichenberger P. (2012) Les organisations patronales suisses entre coordination économique et influence politique. Bilan historiographique et pistes de recherche. Vingtième Siècle. Revue d'Histoire, no 115, pp. 115-127.

Landmann J. (1928) Die Agrarpolitik des Schweizerischen Industriestaates. Jena.

Laur E. (1919) Politique Agraire. Lausanne.

Laurent A., Vallet G. (2014) La construction progressive de l'avantage compétitif financier suisse (1914-1936). Revue d'Économie Financière, no 113, pp. 259-273.

Mendras H. (1967) La Fin des Paysans. Paris.

Musy J.-M. (1933) Déclaration au Conseil Fédéral. Conseil Fédéral, September 26th.

Ponsot J.-F., Vallet G. (2013) Small is beautiful ? La souveraineté monétaire de la Suisse en question. Revue Française de Socio-Économie, no 12, pp. 27-50.

Quartier C. (1978) Paysans Aujourd'hui en Suisse. Lausanne.

Schoenenberger A., Zarin-Nejadan M. (2001) L'Économie Suisse. Paris.

Schumpeter J.A. (2014) Treatise on Money. Aalten.

Schulthess E. (1943) Procès verbal de la conférence économique du 23 avril 1943.

Touraine A. (1994) Qu'est-ce Que la Démocratie? Paris.

Vallet G. (2010) La Suisse et la zone euro: Une zone monétaire optimisée? Revue du Marché Commun et de I'Union Européenne, no 543, pp. 624-635. 
Vallet G. (2012) Should I stay or should I go? Switzerland and the European economic and monetary integration process. Journal of Economic Integration, vol. 27, no 3, pp.366-385.

Vallet G. (2016) A local money to stabilize capitalism: the underestimated case of the WIR. Economy and Society, vol. 45, no 3-4, pp. 479-504.

Vallet G. (2017) Think twice: Using economics and sociology to understand monetary issues: The case of Switzerland. International Review of Sociology, vol.27, no 1, pp. 160-178.

\section{Забытые истоки швейцарской экономической системы: ключевая роль крестьянства в ее историческом развитии}

Гильом Валле, доцент, преподаватель экономики и социологии Департамента социологии, Университет Гренобль Альпы, Гренобль, ВР 47, Франция, з8о4о. E-mail: guillaume.vallet@univ-grenoble-alpes.fr.

В статье показана роль крестьянства в становлении швейцарской производственной системы и общества в целом. По мнению автора, как только речь заходит о крестьянстве в Швейцарии, очевидным становится следующий парадокс: хотя со временем экономическое значение крестьянства снижалось, оно сохраняло свое политическое влияние. На основе архивных данных этот парадокс в статье разрешается, поскольку они подтверждают ключевую историческую и институциональную роль крестьянства в создании так называемой “швейцарской модели", основанной на финансах. Швейцарское крестьянство всегда участвовало в принятии важных политических решений и выполняло значимую культурную функцию поддержания локальных сообществ (центростремительные силы) в рамках небольшой открытой экономики (центробежные силы). Швейцарский кейс призван продемонстрировать взаимосвязь крестьянства как особой по своим функциям социальной группы и национальной производственной системы. Под последней поднимается совокупность секторов национальной экономики, которая требует особого "клея" в виде денежной политики, соответствующей экономическим и социальным структурам. Согласно Й. Шумпетеру, «ничто не показывает столь же ясно, что представляет из себя народ, как его денежная политика... все, чего люди хотят, что они делают и от чего страдают, отражено в национальной денежной системе» (Schumpeter, 2014: xiv). Автор стремится показать значение крестьян как социальной группы в швейцарской производственной системе, утверждая, что они участвовали в создании мощной экономической модели, основанной на швейцарском франке, а потому термин "крестьянство" несет в себе одновременно экономические и культурные черты в заданном историческом контексте. В первой части статьи обозначены нынешние черты швейцарского крестьянства как социальной группы; во второй части описана ее роль в 193о-е годы, период становления мощной национальной производственной системы; в третьей части подытожены выводы относительно ключевой роли швейцарского крестьянства в широком смысле.

Ключевые слова: Швейцария, крестьянство, национальная история, национальная производственная система, социально-экономическая модель, социальные и экономические институты
69

\section{G. Vallet}

The neglected roots of Switzerland's national economy: The key role of peasantry 